\title{
What Explains Indirect Exports of Goods and Services in Eastern Europe and Central Asia?
}

I. Martinez-Zarzoso*,** and F. Johannsen*

*University of Goettingen

**University Jaume I

Published as: Empirica (2018), Volume 45, issue 2, pp 283-309

\section{Abstract}

This paper investigates the determinants of indirect exporting, using firm-level data for 27 countries in Eastern Europe and Central Asia. Indirect exporting depends on a combination of fixed and variable trade cost factors. We first hypothesize that firms that perceive customs, transportation, crime and legal systems as severe obstacles anticipate higher fixed costs and are more likely to export indirectly. The second hypothesis is that indirect exporting tends to be a temporary strategy. Econometric models are used to test the first hypothesis and transition matrices to test the second. In particular, probit, Heckman-probit and fractional response models are estimated to analyse the determinants of the export mode and the share of indirect exports. The results indicate that the factors that account for the fixed cost of exporting, mainly affect the decision to export indirectly (extensive margin), but some of them also affect, to a lesser extent, the amount exported indirectly (intensive margin). More specifically, factors such as customs and trade restrictions and transportation obstacles affect the extensive margin only, whereas crime affects both margins. Secondly, trade agreement membership mainly affects trade in manufactured goods, while exchange rate volatility affects positively the extensive and intensive margin of indirect exports of services. The results also indicate that firms are more likely to change their status as an indirect exporter than they are to change their status as a direct exporter or a non-exporter, which provides support to the second hypothesis.

Key words: intermediaries, indirect exporting, Eastern Europe, Central Asia, uncertainty 
JEL classification: F14, F15, L22, O24

\section{Introduction}

Over the past two decades, there has been a growing interest in the study of the internationalization strategies of firms (Bernard et al. 2003; Bernard and Jensen 2004). Three main sales modes have been considered in the related literature, namely domestic sales, direct exports and exports using an intermediary (indirect exports). A first strand of papers focused on studying the determinants of the choice whether to export or not, without taking into consideration the choice between direct and indirect exporting. According to the seminal paper on that subject by Melitz (2003), firms have to pay a fixed entry cost to access foreign markets along with variable trade costs when their product is exported directly. If the fixed cost is high and expected sales are low, a firm will likely choose to serve only the domestic market. Fixed costs are related to the quality of governance and contracting in a country and in turn to the administrative documents needed to export and the time required to obtain the necessary documentation. The decision mainly depends on the firm's productivity level in comparison to other firms in the country. Only the most productive firms will choose to export, with the less productive firms selling domestically. Trade liberalization will lead to a reallocation of firms within industries and to an increase in average productivity.

As for the choice of whether to export directly or indirectly, theoretical studies that extend the model of Melitz (2003) with intermediaries find that for less productive firms, exporting using a middleman can be an attractive option. According to Blum et al. (2009), these firms choose an intermediation technology that allows them to lower the unit fixed cost of exporting, whereas larger firms select a direct distribution technology to access consumers in foreign markets. Indirect exporting is assumed to have higher marginal costs, but the associated fixed costs are lower or even non-existent (Akerman 2014; Ahn et al. 2011; Felbermayr and Jung 2011; Crozet et al. 2013). All these theoretical models predict the same 
sorting pattern of the different export modes, according to which the least productive firms are non-exporters, whereas those with medium productivity levels use intermediaries to sell their products abroad and only the most productive firms export directly. The models also predict that one of the main factors determining the export mode is the size of the fixed costs of exporting. Firms tend to rely more on intermediaries when fixed costs are high or when destination markets are small and higher-than-average productivity levels are needed to offset lower profits.

Empirical evidence at the firm level identifies several factors that influence the decision to export via a middleman. Specifically, intermediaries reduce search costs for the producing firms (Spulber 1999), facilitate matching of sellers and buyers (Rubinstein and Wolinsky 1987) and can act as guarantor of quality (Biglaiser 1993). According to Bernard et al. (2015), wholesalers in Italy are smaller than direct exporting manufacturers and export a larger variety of products to a smaller number of countries. Like Felbermayr and Jung (2011), they emphasize the importance of intermediaries when firms are exporting to destinations with weak contracting environments and when exporting homogeneous products. Moreover, intermediaries face lower fixed costs of exporting and can therefore easily adjust to changes in demand. Crozet et al. (2013) find that French wholesalers mainly serve countries with smaller market size and higher trade costs than the average destination. Abel-Koch (2013), using survey data for Turkey, shows that indirect exporters are mostly small firms, producing low-quality goods, or introducing an entirely new product to foreign markets, but other factors such as foreign ownership or the existence of credit constraints do not influence the decision to export indirectly. Also using World Bank survey data, Zerihun (2012) provides evidence for firms in sub-Saharan Africa, showing that the decision to export indirectly is negatively influenced by firm size, being a subsidiary of a multi-plan firm and having access 
to information technology. Conversely, it is positively affected by firms' perceptions of obstacles in the form of corruption or access to finance.

A recent study by McCann (2013) that used firm-level data to examine the determinants of export behaviour in Eastern Europe and Central Asia, finds that the productivity of indirect exporters lies between the productivity levels of direct and non-exporters. His main findings are that multiproduct firms, despite being more productive, are more likely to export indirectly than single-product firms and that the sunk costs of indirect exporting are significantly lower than those associated with direct exporting.

In the abovementioned studies, little emphasis has been placed on the role of perceived uncertainty in the exporting country in the decision to export indirectly. To export directly, a firm has to deal with several potential obstacles that can entail additional costs of unforeseeable amounts. These obstacles include, among others, domestic and foreign bureaucracy and corruption, customs procedures and trade regulations, transportation and cross-border financial transactions. Due to the uncertainty relating to these costs, risk-averse firms may choose to use a middleman in some markets in order to lower their overall exposure to changes in the fixed cost of exporting. Risk-averse firms may also want to test demand in a foreign market using an intermediary before paying the fixed costs of entry for direct exporting. This is particularly true when fixed costs are high or market potential is low.

Like Abel-Koch (2013) and McCann (2013), we also use survey data from the World Bank. However, we differ from those authors in that we investigate the determinants of the decision of whether to export directly or via intermediaries with a special focus on firms' perception of uncertainty in the country where they operate ${ }^{1}$, which mainly affects fixed costs of exporting.

\footnotetext{
${ }^{1}$ Unfortunately, the data does not contain information about the destination of exports. We believe that since the number of export destinations grows with firm size, controlling for firm size but not being able to control for the number of destinations of a firm's exports may lead us to underestimate the negative relation between firm size and indirect exports (Abel-Koch, 2013).
} 
In particular, we take into consideration factors such as transportation hold-ups, crime, weak legal systems, trade policy and exchange rate volatility. To our knowledge, this is the first paper to investigate these issues with a wider variety of measures used as proxies for perceived obstacles to trade. Most of these measures are proxies for the "perceived" size of the fixed cost of exporting and are firm specific (customs and trade regulations, transportation hold-ups, crime, weak legal systems). Others are country specific and relate to exchange rate volatility and to trade policy, and could be linked to the fixed and the variable costs. In addition, we distinguish between trade in goods and trade in services, though we exclude retailers and wholesalers from the service sector, as the characteristics of the latter two activities are different and could be affected by uncertainty in different ways. As in McCann (2013), we focus on Eastern Europe and Central Asia because in these countries political instability, corruption and criminality are widespread and act as a barrier to a wellfunctioning market economy ${ }^{2}$. Departing from McCann (2013), we consider goods and services and our main focus is not multiproduct firms but rather the effect of uncertainty on the internationalization strategies of firms in Eastern Europe and Central Asia ${ }^{3}$, since there are no papers to date that have examined this issue.

We assume that poor institutional quality hinders the conditions in which firms (potential exporters) have to operate and hence increases uncertainty and transaction costs (De Groot and Linders et al, 2004). This uncertainty is a greater threat to potential direct exporters and can be avoided by using an intermediary, at least as a "foot in the door" strategy. As proxies for fixed export costs, we employ firm-specific measures based on the manager's perception

\footnotetext{
${ }^{2}$ According to the Doing Business dataset (World Bank) the average time and cost for obtaining, preparing, processing, presenting and submitting documents for exports is 30 hours in the region under study compared to 4.5 hours in high-income OECD countries, and the average cost for documentary compliance is 143 USD, whereas in high-income OECD countries it is only 35.6 USD.

${ }^{3}$ McCann (2013) is the only previous paper that focuses on Eastern Europe and Central Asia. However, his main aim is different to ours, as he gives descriptive evidence of the characteristics of indirect exporters, compares the likelihood of exporting indirectly for single-product and multi-product firms and focuses exclusively on manufacturing firms, excluding the service sector from the analysis.
} 
of the extent to which administrative or legal burdens affect a firm's decision to start exporting indirectly.

The modelling strategy consists of estimating a probit model to investigate the determinants of the decision to export indirectly and a fractional regression model to examine the factors affecting the intensity of indirect exporting. As robustness checks, we use a narrow definition of indirect exporters and also a Heckman-Probit with selection to examine whether the decision to export indirectly could be consider independent from the decision to export or not. Finally, we also consider a second step fractional regression that estimates the share of indirect exports with respect to total exports and includes the inverse Mills ratio from the Heckman-Probit model to control for sample selection.

The main results confirm the hypothesis that indirect exporting tends to be a temporary strategy in both the goods and the services sectors. Secondly, concerning the export premia the results mainly follow the same hierarchy predicted by the theoretical models, with two exceptions. First, in the manufacturing sector, indirect-only exporters are not more productive than domestic firms, whereas for services, firms using a mixed exporting strategy (broad definition of indirect exporters) have a slightly higher labour productivity than direct exporters. The results found for services are new in the literature. Finally, the empirical estimations suggest that the decision to export indirectly is positively influenced by the perception of customs and trade regulations, transportation and crime as being obstacles to exporting. Moreover, larger and more productive firms tend to export a smaller share of their exports indirectly. Export intensity is negatively correlated with indirect exporting, whereas EU and CEFTA membership favours direct exporting of goods, but not of services. Finally, the perception of obstacles stemming from crime also leads to an increased share of indirect exports in goods, whereas exchange rate volatility favours indirect exporting and increase the share of indirect exporters in the service sector. 
The rest of the paper is structured as follows. Section 2 describes the data and the empirical approach, section 3 outlines the main results and robustness checks, and section 4 presents the conclusions.

\section{Empirical Analysis}

\subsection{Data and variables}

We focus specifically on the firm's perception of obstacles to trading in the source country and their influence on the decision of whether to export directly or via an intermediary. In order to obtain the variables that are used as determinants of this decision, we combine information from the World Bank Enterprise Business Environment and Enterprise Performance Survey (BEEPS) with country-specific information on regional integration and exchange rate volatility of the different currencies with respect to the euro and with respect to the currencies of the main trading partners ${ }^{4}$. Data on exchange rates with respect to the euro comes from OANDA Corporation. A description of the variables is shown in Table A.1.

The dataset includes information taken from BEEPS for 27 countries, four years (2002, 2005, 2007 and 2009) and 18 sectors (See Table A.2 in the Appendix for a list of sectors and number of firms by exporting status and Table A.3 for a list of countries and number of firms by country and sector). It can be seen that there are 10385 manufacturing firms and 16509 services firms. In the manufacturing sector 30 percent of the firms are direct exporters, whereas almost 59 percent sell only to the domestic market. The rest, around 10 percent of the firms, are indirect exporters, out of which 5.6 percent also export directly. Within the service sector, wholesalers and retailers represent around 46 percent of the total, but since firms in these industries do not usually produce what they sell and the theoretical distinction between direct and indirect exporters is unclear, we exclude these two sectors from the

\footnotetext{
${ }^{4}$ Two alternative exchange rate measures are considered to calculate exchange rate volatility. First, the bilateral exchange rate with respect to the USD and second, a nominal effective exchange rate weighted with trade shares using 138 destinations of exports (Darvas (2012)).
} 
empirical analysis. The remaining industries are construction, hotels and restaurants, transport and information technology services. The highest share of indirect exporting firms is in the transportation industry, in which around 11 percent of firms export the service indirectly (5.2 are indirect exporters and 5.9 percent use a mixed exporting strategy). Direct exporting is a less important mode of internationalization for the service sector than for the goods sector in general, with only 13 percent of firms using this mode of exporting exclusively. Finally, in the service sector around 83 percent of the firms sell their services in the domestic market only, indicating the intrinsically non-tradable nature of many services.

An important issue is to understand how indirect exporting is defined in services, and in particular in some of the services categories in which indirect exporting shows the highest shares (the transportation, hotels and restaurants and IT sectors). More specifically, we look at the descriptions given in the questionnaires concerning the main services exported indirectly. These include services from the hotels and restaurants sector (hotel catering supply, hotel service, tourist information services, transit and bus rental, and tour packages), from the transportation sector (international transport of goods, marine transport, passenger transportation and transit of cargo), and from the IT sector (internet services, other computerrelated activities and other software consultancy and supply).

A number of variables related to transaction costs and uncertainty are selected from the surveys, including foreign ownership, perception of the obstacles to a firm's activities presented by transportation, customs and trade regulations, crime, corruption, business permits and licences, the legal system, and time needed to clear customs. The surveys used stratified random sampling techniques to select a representative sample for each country using industry, firm size and region as levels of stratification.

We use a broad definition of indirect exports so that this category includes all firms that export through an intermediary, as well as those using a mixed exporting strategy with part of 
their foreign sales exported directly ${ }^{5}$. Table A.3 in the Appendix shows the list of countries included in the analysis and the distribution of exporting firms for all sectors across all countries. The largest sectors in the sample in terms of number of firms are retail, food, wholesale and other manufacturing. Concerning the countries in the sample, Russia, Poland, Ukraine and Bulgaria have the largest share of firms in the dataset. Summary statistics of firm- and country-specific variables are shown in Table 1 . The average share of exports over total sales is almost 11.5 percent (Export Intensity), with almost 8 percent on average exporting indirectly. About 15 percent of the firms are at least partly foreign owned, and while 27 percent are based in a European Union (EU) member country, 42 percent are located in a Central European Free Trade Agreement (CEFTA) member country.

\section{Table 1. Summary Statistics}

\begin{tabular}{|c|c|c|c|c|c|}
\hline Variable & Obs & Mean & Std. Dev. & Min & Max \\
\hline \multicolumn{6}{|c|}{ Dependent variable } \\
\hline Indirect exports $_{\mathrm{ijkt}}$ & 19,218 & 0.079 & 0.269 & 0 & 1 \\
\hline \multicolumn{6}{|c|}{ Firm-specific variables } \\
\hline In N Employees Eijkt $_{\text {. }}$ & 19,137 & 3.466 & 1.612 & 0 & 10.539 \\
\hline In Labor Prod ijkt & 14,909 & 10.122 & 1.775 & 1.565 & 26.843 \\
\hline Export intensity $_{i j k t}$ & 19,149 & 11.478 & 25.908 & 0 & 100 \\
\hline Foreign $_{i j k t}$ & 19,218 & 0.150 & 0.357 & 0 & 1 \\
\hline Transportation $_{\mathrm{ijkt}}$ & 18,823 & 0.737 & 1.117 & 0 & 4 \\
\hline Customs $_{\mathrm{ijkt}}$ & 17,046 & 0.919 & 1.140 & 0 & 4 \\
\hline Crime $_{i j k t}$ & 18,513 & 1.044 & 1.205 & 0 & 4 \\
\hline Legal system $_{\mathrm{ijkt}}$ & 17,382 & 2.501 & 0.981 & 1 & 4 \\
\hline Customs time $_{\mathrm{ijkt}}$ & 4,121 & 3.696 & 7.379 & 0 & 120 \\
\hline \multicolumn{6}{|c|}{ Country-specific variables } \\
\hline $\mathbf{E} \mathbf{U}_{\mathrm{jt}}$ & 19,239 & 0.272 & 0.445 & 0 & 1 \\
\hline CEFTA $_{\text {it }}$ & 19,239 & 0.425 & 0.494 & 0 & 1 \\
\hline VolatilityEuro $_{\text {jt-1 }}$ & 15,693 & 0.026 & 0.050 & 0 & 0.470 \\
\hline Volatility $E R_{\text {it-1 }}$ & 18,061 & 0.018 & 0.023 & 0.002 & 0.197 \\
\hline
\end{tabular}

Note: See Appendix A.1 for a description of the variables. Wholesalers and retailers are excluded from the sample.

\footnotetext{
${ }^{5}$ This is the definition used by McCann (2013) for indirect exports in the core of his paper. We also present results by using a narrow definition, in this case indirect exporters that also export directly are excluded (see results in tables 3,4 and A.5).
} 
In the survey, some firms have been interviewed on a number of separate occasions over the years, but when we restrict the dataset to firms that have been interviewed at least twice, the sample size is considerably reduced (with 6302 observations left corresponding to 2409 firms ${ }^{6}$ ). By using only those firms in the regression analysis we could be creating a sample selection problem, since it is likely that firms that appear several times are better performers than those that are only included once. In any case, we are able to track firms that stay in the panel and use this reduced sample to test whether indirect exporting is mainly used as a temporary strategy to enter foreign markets. Table 2 shows the transition matrix of firms for the whole panel (excluding retailers and wholesalers for the abovementioned reasons) and also for firms in the manufacturing and the service sectors separately. Export status is displayed in the columns and its lag in the rows of the matrix (Table 2). The figures show that almost 90 percent of firms that were non-exporters in a given period continued to be nonexporters in the following period; the figure is considerably higher for firms in the services sector (92) than for those in the manufacturing sector (86). The other figures in the first row show very low percentages, indicating that non-exporters are very likely to stay as such. More mobility is observed in the manufacturing sector, however, with 2.3 percent of firms becoming indirect exporters and an additional 2.3 percent moving to a mixed exporting strategy using direct and indirect exporting, while 9 percent change to direct exporting.

Firms that remain indirect-only exporters account for 9.6 percent of the manufacturing sector, while no firms in the services sector retain that status in the following observed period. A similarly small share is observed for firms moving from a mixed exporting strategy to only indirect exporting (8.6 percent in the manufacturing sector). However, in the manufacturing sector, a high share of firms, 50 percent, progressed from only indirect exporting to only

\footnotetext{
${ }^{6}$ Although the number of observations is considerably reduced (19218 in the whole sample excluding retailers and wholesalers), it allows us to provide some insight into the hypothesis that indirect exports tend to be a temporary strategy.
} 
direct exporting, and a considerable share (41 percent) changed from a mixed exporting strategy to only direct exporting. There was also a marked movement towards direct exporting in the services sector but with more firms moving from a mixed exporting strategy to direct exporting (52 percent) than from only indirect exporting to direct exporting (35 percent). Although almost 62 percent of firms in manufacturing (42 in services) remained direct exporters, it is worth mentioning that a substantial share of firms using a mixed exporting strategy also retained the same status in the following period (37 and almost 24 percent, respectively, in each sector).

Table 2. Transition matrix of export status for firms appearing at least twice in the data

\begin{tabular}{|c|c|c|c|c|c|c|c|c|c|c|c|c|c|c|c|}
\hline \multirow{3}{*}{$\begin{array}{l}\text { Mode } \\
\text { Time: } \\
(\mathrm{t}-1)\end{array}$} & \multicolumn{5}{|c|}{$\begin{array}{l}\text { All firms excluding retailers and } \\
\text { wholesalers }\end{array}$} & \multicolumn{5}{|c|}{ Manufacturing sector } & \multicolumn{5}{|c|}{$\begin{array}{l}\text { Services without retailers and } \\
\text { wholesalers }\end{array}$} \\
\hline & $\mathrm{t}$ & \multicolumn{3}{|c|}{ Mode (\%) } & \multirow{2}{*}{$\begin{array}{l}\text { Total } \\
\text { No }\end{array}$} & \multicolumn{4}{|c|}{ Mode (\%) } & \multirow{2}{*}{$\begin{array}{l}\text { Total } \\
\text { No }\end{array}$} & \multicolumn{4}{|c|}{ Mode (\%) } & \multirow{2}{*}{$\begin{array}{l}\text { Total } \\
\text { No }\end{array}$} \\
\hline & NX & IX & IDX & $\mathrm{DX}$ & & NX & IX & IDX & DX & & NX & IX & IDX & DX & \\
\hline NX & 89.8 & 1.8 & 1.5 & 6.9 & 1,446 & 86.2 & 2.3 & 2.3 & 9.3 & 527 & 92 & 1.5 & 1.0 & 5.2 & 842 \\
\hline IX & 33.3 & 6.7 & 14.7 & 45.3 & 75 & 26.9 & 9.6 & 13.5 & 50.0 & 52 & 47.8 & 0.0 & 17.4 & 34.8 & 23 \\
\hline IDX & 14.8 & 6.2 & 33.3 & 45.7 & 81 & 12.1 & 8.6 & 37.9 & 41.4 & 58 & 23.8 & 0.0 & 23.8 & 52.4 & 21 \\
\hline $\mathrm{DX}$ & 28.0 & 7.1 & 9.3 & 55.6 & 592 & 19.9 & 8.7 & 9.7 & 61.7 & 392 & 43.8 & 4.6 & 9.7 & 42.1 & 176 \\
\hline Total & 68.5 & 3.6 & 5.2 & 22.7 & 2,194 & 53.7 & 5.4 & 7.7 & 33.1 & 1,029 & 81.9 & 2.0 & 3.2 & 12.9 & 1,062 \\
\hline
\end{tabular}

Note: NX, IX, IDX and DX denote respectively non-exporters, indirect exporters, firms that export both directly and indirectly and direct exporters.

\subsection{Performance premia}

In this sub-section we estimate the performance premia for indirect and direct exporters in terms of labour productivity and number of employees, in order to provide some insight in relation to the sorting pattern that the theory predicts. We should expect that indirect exporters enjoy a productivity advantage over domestic firms and that direct exporters are in turn more productive than indirect exporters. Figure A.1 in the appendix shows the distribution of labour productivity for non-exporters, indirect exporters and direct exporters. 
Direct exporters appear to have a productivity advantage over indirect exporters ${ }^{7}$ and the latter appear to be more productive than non-exporters. A similar pattern is expected in relation to firm size: the theory predicts that direct exporters are bigger in size than indirect exporters and the latter are in turn bigger than non-exporters. Tables 3 and 4 present separate results for services and manufacturing activities using the natural log of labour productivity and employment as dependent variables, respectively. The first three columns use the narrow definition of indirect exporters, whereas columns (4) to (6) use the broader definition (including firms that export directly as well as indirectly).

Looking at the results in Table 3, when all firms are included in the first column, the estimated coefficients for direct exporters lie above the coefficient for indirect exporters (and significantly above those for domestic firms, which is the excluded category), confirming the performance hierarchy predicted by the theory. However, in the manufacturing sector, indirect exporters (narrow definition, column 2) are not more productive than domestic firms, whereas for services, firms using a mixed exporting strategy (broad definition of indirect exporters) have a slightly higher labour productivity than direct exporters.

Table 3. Export mode and labour productivity

\begin{tabular}{|c|c|c|c|c|c|c|}
\hline \multicolumn{4}{|c|}{ Narrow definition of indirect exporter } & \multicolumn{3}{|c|}{ Broad definition of indirect exporter } \\
\hline & (1) & $(2)$ & (3) & (4) & $(5)$ & (6) \\
\hline VARIABLES & All & Manu & Serv & All & Manu & Serv \\
\hline \multicolumn{7}{|l|}{ Indirect } \\
\hline \multirow[t]{2}{*}{ exporter } & $0.112^{* *}$ & 0.0461 & $0.297 * * *$ & $0.201 * * *$ & $0.146^{* * *}$ & $0.368^{* * *}$ \\
\hline & {$[0.0480]$} & {$[0.0564]$} & {$[0.0768]$} & {$[0.0367]$} & {$[0.0447]$} & {$[0.0508]$} \\
\hline \multirow[t]{2}{*}{ Direct exporter } & $0.281 * * *$ & $0.260 * * *$ & $0.330 * * *$ & $0.305^{* * *}$ & $0.286 * * *$ & $0.349 * * *$ \\
\hline & {$[0.0240]$} & [0.0298] & [0.0407] & {$[0.0256]$} & [0.0324] & [0.0421] \\
\hline Observations & 14,909 & 8,208 & 6,701 & 14,909 & 8,208 & 6,701 \\
\hline R-squared & 0.722 & 0.727 & 0.719 & 0.723 & 0.727 & 0.720 \\
\hline
\end{tabular}

\footnotetext{
${ }^{7}$ The advantage of direct exporters over indirect exporters is clearer when the narrow definition of indirect exporters is used (indirect-only exporters).
} 
In terms of employment, results in Table 4 clearly confirm that indirect exporters are significantly bigger than non-exporters and indirect exporters are significantly smaller than direct exporters, using either of the definitions of indirect exporters and for both manufacturing and services activities.

Table 4. Export mode and firm size

\begin{tabular}{|c|c|c|c|c|c|c|}
\hline \multicolumn{4}{|c|}{ Narrow definition of indirect exporter } & \multicolumn{3}{|c|}{ Broad definition of indirect exporter } \\
\hline & $(1)$ & $(2)$ & (3) & (4) & (5) & (6) \\
\hline VARIABLES & All & Manu & Serv & All & Manu & Serv \\
\hline \multicolumn{7}{|l|}{ Indirect } \\
\hline \multirow[t]{2}{*}{ exporter } & $0.721^{* * *}$ & $0.880 * * *$ & $0.380 * * *$ & $1.039 * * *$ & $1.303^{* * *}$ & $0.487 * * *$ \\
\hline & {$[0.0676]$} & {$[0.0796]$} & [0.108] & {$[0.0590]$} & {$[0.0554]$} & [0.114] \\
\hline \multirow[t]{2}{*}{ Direct exporter } & $1.105^{* * *}$ & $1.315^{* * *}$ & $0.641 * * *$ & $1.214 * * *$ & $1.490 * * *$ & $0.667 * * *$ \\
\hline & {$[0.0443]$} & {$[0.0405]$} & {$[0.0714]$} & {$[0.0475]$} & {$[0.0403]$} & [0.0733] \\
\hline Observations & 19,137 & 10,332 & 8,805 & 19,137 & 10,332 & 8,805 \\
\hline R-squared & 0.188 & 0.227 & 0.139 & 0.208 & 0.271 & 0.141 \\
\hline
\end{tabular}

Note: Robust standard errors in brackets at the country and industry level. ${ }^{* * *} \mathrm{p}<0.01,{ }^{* *} \mathrm{p}<0.05,{ }^{*} \mathrm{p}<0.1$. Retailers and wholesalers are excluded from the regressions. In (4)-(6) indirect exporters also include firms that also export directly. All regressions include sectoral dummies, and country and time dummies.

The results concerning manufacturing firms are comparable to those found in McCann (2013), whereas the results found for services are new in the literature and mainly follow the same hierarchy predicted by the theoretical models. There is however an exception: service firms using a mixed strategy, that is exporting both directly and indirectly, are more productive than direct-only exporters.

\subsection{Model Specification}

The first part of our econometric approach consists of estimating a probit model with country and time-variant industry dummies to explain the probability of exporting indirectly. In a second step, we estimate a fractional regression (Oberhofer, H. and Pfaffermayr, 2102; Papke and Wooldridge, 1996) using the share of indirect exports over total exports as the dependent variable. As a robustness check, we use a two-stage approach (probit with 
selection+factional regression) to correct for potential sample selection biases. The specification of the probit model used to predict indirect exports is given by:

$$
\begin{gathered}
\operatorname{Pr}\left(\text { IndirectExporter }_{i j k t}=1\right)=\Phi\left(\beta_{0}+\beta_{1} \ln \text { Employees }_{i j k t}+\beta_{2} \text { LaborProd }_{i j k t}+\right. \\
\beta_{3} \text { Exportintensity }_{i j k t}+\beta_{4} \text { Foreign }_{i j k t}+\beta_{5} \text { Transportation }_{i j k t}+\beta_{6} \text { Customs }_{i j k t}+\beta_{7} \text { Crime }_{i j k t}+ \\
\left.\beta_{8} \text { Legalsystem }_{i j k t} \beta_{9}+\text { Customstime }_{i j k t}+\beta_{10} \text { EU }_{j t}+\beta_{11} \text { CEFTA }_{j t}+\beta_{12} \text { Volatility }_{j t-1}+\kappa_{j}+\lambda_{k t}+\varepsilon_{i j k t}\right)
\end{gathered}
$$

where IndirectExporter ${ }_{\mathrm{ijkt}}$ is a dummy variable that takes the value of one if firm $i$ in country $j$ and sector $k$ exports a part of its foreign sales using an intermediary and zero if all exports are

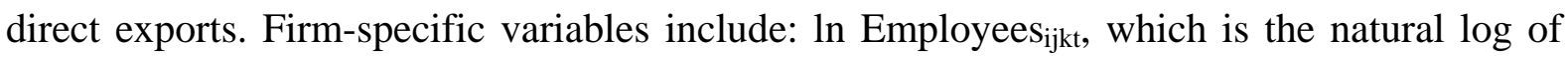
the total number of permanent full-time workers; ln LaborProd $\mathrm{ijkt}_{\text {for }}$ the natural log of total annual sales divided by the number of workers; Exportintensity ${ }_{\mathrm{ijk}}$, which denotes the share of exported sales and it is included to denote the importance of the international exposure of the firm as a factor that could influence the mode of exporting; and Foreign ${ }_{\mathrm{ijk}}$, which is a dummy variable that takes the value of one when a firm is partly owned by a foreign individual or firm and zero otherwise. A firm's perception of obstacles is captured by three different variables: transportation of goods, supplies and inputs (Transportation ${ }_{\mathrm{ijkt}}$ ); customs and trade regulation (Customs $s_{\mathrm{ijkt}}$ ); and crime, theft and disorder $\left(\mathrm{Crime}_{\mathrm{ijkt}}\right)$, all of which are originally measured on a scale from zero to four ${ }^{8}$. The perceived fairness of the legal system (Legalsystem ${ }_{\mathrm{ijkt}}$ ) is measured on a scale from one to four, while for time efficiency of customs authorities (Customstime ${ }_{\mathrm{ijkt}}$ ) the number of days needed to clear customs is used. We introduce country-specific dummy variables that take the value one if country $j$ is a member

\footnotetext{
${ }^{8}$ We have re-scaled the variable customs, which takes the value of 1 if customs and trade regulations are a severe or very severe obstacle for current operations of the firm, 0 otherwise. Another two variables, corruption and permits are also used in some models; they are described in Table A.1 in the Appendix. In particular, corruption is used in the Heckman-Probit model as exclusion restriction and permit is used in the regressions for the service sector.
} 
of the European Union $\left(\mathrm{EU}_{\mathrm{jt}}\right)$ or the Central European Free Trade Agreement $\left(\mathrm{CEFTA}_{\mathrm{jt}}\right)$ in year $t$, and a measure of volatility for the nominal exchange rate of the domestic currency (Volatility $\mathrm{j}_{\mathrm{jt}-1}$ ). Exchange rate volatility is defined as the standard deviation of the first difference of the logarithms of the monthly domestic nominal bilateral exchange rate of each domestic currency with respect to the euro for the 12 months of the previous year:

$$
\text { Volatility }_{j t-1}=\text { Std. dev. }\left[\ln \left(e_{j, m}\right)-\ln \left(e_{j, m-1}\right)\right], m=1 \ldots 12 .(2)
$$

where $m$ denotes month and $e$ is the nominal bilateral exchange rate.

In a next step, we estimate the determinants of a firm's intensity of indirect exports using a fractional regression with two sets of dummy variables (country and sector-time):

$$
\begin{gathered}
\text { Indirectexports }_{\mathrm{ijkt}}=\mathrm{G}\left(\beta_{0}+\beta_{1} \operatorname{lnEmployees}_{\mathrm{ijkt}}+\beta_{2} \text { LaborProd }_{\mathrm{ijkt}}+\beta_{3} \text { Exportintensity }_{\mathrm{ijkt}}+\right. \\
\beta_{4} \text { Foreign }_{\mathrm{ijkt}}+\beta_{5} \text { Transportation }_{\mathrm{ijkt}}+\beta_{6} \text { Customs }_{\mathrm{ijkt}}+\beta_{7} \text { Crime }_{\mathrm{ijkt}}+\beta_{8} \text { Legalsystem }_{\mathrm{ijkt}}+ \\
\left.\beta_{9} \text { Customstime }_{\mathrm{ijkt}}+\beta_{10} \text { EU }_{\mathrm{jt}}+\beta_{11} \text { CEFTA }_{\mathrm{jt}}+\beta_{12} \text { Volatility }_{\mathrm{jt}-1}+\kappa_{\mathrm{j}}+\lambda_{\mathrm{kt}}+\varepsilon_{\mathrm{ijkt}}\right)
\end{gathered}
$$

where $G(\cdot)$ is a know nonlinear function satisfying $0 \leq G(\cdot) \leq 1$. The dependent variable is the share of indirect exports over total exports for firm $i$ in country $j$ in year $t$. All other variables are identical to the model in (1). Since the dependent variable only varies within the interval $(0,1)$ we use a fractional probit regression, which is more appropriate for this response variable.

The previous two models assume that firms decide whether or not to export before deciding about the modality and that both these decisions are made independently of each other. If they choose to export, firms then also have to decide the amount to export indirectly. Hence, before deciding on the intensity of indirect exporting, firms go through two stages of decision-making: first, whether or not to enter the export market, and second, whether to export directly or indirectly. An appropriate empirical approach should control for both of these decisions before exploring the determinants of the share of indirect exports. At a minimum we should test for the independence of the decisions in the modelling framework. 
In what follow, we explain the modelling strategy, but since we do find that the decisions are independent we keep the previous two models as main results.

Following the approach of Roodman (2001) and Roodman and Murdock (2014) ${ }^{9}$, we estimate a recursive mixed model with selection that allows us to control for sample selection biases and to relax the assumption that the error terms in different equations are independent. The first bias is caused by ignoring non-exporters. Hence, we estimate a Heckman-Probit model in which the decision to export indirectly could be influenced by the decision to export. The first step equation of this Heckman is a probit model on the decision to export or not:

$$
\begin{gathered}
\operatorname{Pr}\left(\text { Exporter }_{i j k t}=1\right)=\Phi\left(\beta_{0}+\beta_{1} \ln \text { Employees }_{i j k t}+\beta_{2} \text { LaborProd }_{i j k t}+\beta_{3} \text { Foreign }_{i j k t}+\right. \\
\beta_{4} \text { Transportation }_{i j k t}+\beta_{5} \text { Customs }_{i j k t}+\beta_{6} \text { Crime }_{i j k t}+\beta_{7} \text { Legalsystem }_{i j k t}+ \\
\left.\beta_{8} \text { EU }_{j t}+\beta_{9} \text { CEFT }_{j t}+\beta_{10} \text { Volatility }_{j t-1}+\text { corruption }_{i j k t}+\kappa_{j}+\lambda_{k t}+\varepsilon_{i j k t}\right)
\end{gathered}
$$

In order to fulfil the exclusion restriction in the Heckman-Probit, we use a variable that only affects the probability of exporting, but not the probability of indirect exporting. Specifically, we use the variable measuring the perception of corruption as an obstacle, which does not affect the probability of indirect exports ${ }^{10}$. We therefore exclude this variable from the estimation in the second stage.

The main equation is a probit model on the decision to export indirectly or directly as given by equation (1) above. Finally, we estimate from the Heckman-Probit the inverse Mills ratio and added it as regressor to the fractional regression specified above (Equation 3).

The second step equation is given by:

$$
\begin{gathered}
\text { Indirectexports }_{i j k t}=G\left(\beta_{0}+\beta_{1} \ln \text { Employees }_{i j k t}+\beta_{2} \text { LaborProd }_{i j k t}+\right. \\
\beta_{3} \text { Foreign }_{i j k t}+\beta_{4} \text { Transportation }_{i j k t}+\beta_{5} \text { Crime }_{i j k t}+\beta_{6} \text { Legalsystem }_{i j k t}+.(5) \\
\left.\beta_{7} \text { EU }_{j t}+\beta_{8} \text { CEFTA }_{j t}+\beta_{9} \text { Volatility }_{j t-1}+\text { IMR_indexport }+\kappa_{j}+\lambda_{k t}+\varepsilon_{i j k t}\right)
\end{gathered}
$$

In the second step regression, we include the inverse Mill's ratio (IMR_indexport) in the

\footnotetext{
${ }^{9}$ Rodman's cmp stata command allows for a large class of simultaneous-equation systems, including recursive models, in which endogenous variables could influence one another.

${ }^{10}$ Results are available upon request from the authors.
} 
model as a correction for sample selection, which address the biases generated by unobserved shocks.

\section{Main Results}

Results from the probit estimation denoted in equation (1) are shown in Table 5 in the form of marginal effects at mean values of the independent variables. Several estimations including different sets of dummy variables and control variables were carried out ${ }^{11}$ and the preferred results include country dummies and interactions between industry and year dummies, with the standard errors clustered at the country-industry level. Columns (2) and (3) include two alternative measures of exchange rate volatility: first, the volatility calculated as specified in equation (2); and second, using a trade-weighted effective exchange rate based on trade with 138 countries. Finally, column (4) contains the variable measuring time intensity of customs procedures, for which there are many missing observations.

According to our estimates in column (1), the marginal effects of firm size and labour productivity are statistically significant at conventional levels only in columns (2) and (3), whereas export intensity is significant at the one percent level in all specifications and shows a negative coefficient. In particular, column (1) shows that an increase in overall export intensity of 10 percentage points decreases the probability of using an intermediary by 0.54 percent.

Foreign ownership does not seem to affect the decision to export indirectly. While obstacles related to the fairness of the legal system do not show a statistically significant effect, customs impediments and trade regulations ${ }^{12}$, transportation of goods and supply of inputs, as

\footnotetext{
${ }^{11}$ Results using country, year and industry dummies were not substantially different and are available upon request.

12 This variable has been coded as 1 if the customs are a major or very severe obstacle and 0 otherwise. Assuming that this is a fixed cost that could affect the decision to export or not and the decision to export indirectly or directly, we now consider that when the value is 3 or 4, the fixed costs are an obstacle to export, whereas when the answer is $0-3$, the obstacle does not impede exporting.
} 
well as crime, disorder and theft, significantly increase the probability of exporting indirectly. A 1-point increase in the perception of the severity of these obstacles increases the probability of indirect exporting by around 1.2 percentage points for transportation and 1.3 percentage points for crime, disorder and theft and when customs is a severe obstable the probability increases by 5.3 percentage points. An increase in the time needed to clear customs does not seem to increase the probability of exporting indirectly, however this could be due to the fact that the sample is reduced by 30 percent due to missing data in this variable. Higher exchange rate volatility does not seem to promote indirect exporting. Finally, EU membership reduces the probability of using an intermediary, but this is not the case with CEFTA membership.

Linking these results to the theoretical predictions, we find that three of the specific components of uncertainty that are related to the fixed cost of exporting, namely, transportation; crime, disorder and theft; and customs and trade regulations do increase the probability of exporting indirectly, whereas firm size and labour productivity do not significantly affect the decision to export indirectly. Concerning membership in integration agreements, it appears that uncertainty is clearly reduced for countries that have joined the EU, whereas the CEFTA is a more instable and changing agreement, with many of the initial members now forming part of the EU. It is possible that EU membership reduces "behind the border" trade barriers, facilitating export procedures and thereby lowering the fixed costs of exporting. Finally, the uncertainty related to exchange rate volatility could be specific to certain sectors. This will be investigated in the next sub-section.

\section{Table 5. Probit Regression Results}

\begin{tabular}{lllll}
\hline & $(1)$ & $(2)$ & $\begin{array}{l}(3) \\
\text { Ind. Ex- } \\
\text { ports }\end{array}$ & Ind. Exports \\
Dep. variable: & Ind. Exports & Ind. Exports & & \\
\hline Ind. Variables: & & & & \\
Ln N Employees & -0.00534 & -0.00610 & -0.00525 & 0.00507 \\
& $(0.00647)$ & $(0.00638)$ & $(0.00631)$ & $(0.00634)$ \\
\hline
\end{tabular}




\begin{tabular}{|c|c|c|c|c|}
\hline Ln Labour Productivity & $\begin{array}{l}-0.00705 \\
(0.00578)\end{array}$ & $\begin{array}{l}-0.0107 * * \\
(0.00532)\end{array}$ & $\begin{array}{l}-0.0182 * * * \\
(0.00706)\end{array}$ & $\begin{array}{l}-0.000385 \\
(0.00368)\end{array}$ \\
\hline Export Intensity & $\begin{array}{l}-0.00540 * * * \\
(0.000285)\end{array}$ & $\begin{array}{l}-0.00532 * * * \\
(0.000286)\end{array}$ & $\begin{array}{l}0.00525^{* * *} \\
(0.000290)\end{array}$ & $\begin{array}{l}-0.00147 * * * \\
(0.000242)\end{array}$ \\
\hline Foreign & $\begin{array}{l}0.000319 \\
(0.0159)\end{array}$ & $\begin{array}{l}0.00118 \\
(0.0160)\end{array}$ & $\begin{array}{l}-0.00153 \\
(0.0179)\end{array}$ & $\begin{array}{l}-0.0147 \\
(0.0136)\end{array}$ \\
\hline Transport & $\begin{array}{l}0.0120^{* *} \\
(0.00472)\end{array}$ & $\begin{array}{l}0.0114^{* *} \\
(0.00504)\end{array}$ & $\begin{array}{l}0.0106^{* *} \\
(0.00521)\end{array}$ & $\begin{array}{l}0.0159 * * * \\
(0.00398)\end{array}$ \\
\hline Customs & $\begin{array}{l}0.0534^{* *} \\
(0.0267)\end{array}$ & $\begin{array}{l}0.0579 * * \\
(0.0294)\end{array}$ & $\begin{array}{l}0.0664 * * \\
(0.0289)\end{array}$ & $\begin{array}{l}0.0780 * * \\
(0.0354)\end{array}$ \\
\hline Crime & $\begin{array}{l}0.0142 * * \\
(0.00630)\end{array}$ & $\begin{array}{l}0.0139 * * \\
(0.00635)\end{array}$ & $\begin{array}{l}0.0139 * * \\
(0.00651)\end{array}$ & $\begin{array}{l}0.00739 \\
(0.00695)\end{array}$ \\
\hline Legal System & $\begin{array}{l}-0.0121 \\
(0.00816)\end{array}$ & $\begin{array}{l}-0.0131 \\
(0.00806)\end{array}$ & $\begin{array}{l}-0.0110 \\
(0.00744)\end{array}$ & $\begin{array}{l}-0.00646 \\
(0.00840)\end{array}$ \\
\hline EU & $\begin{array}{l}-0.0648 * \\
(0.0333)\end{array}$ & $\begin{array}{l}-0.0602^{* *} \\
(0.0297)\end{array}$ & $\begin{array}{l}-0.0588 * \\
(0.0320)\end{array}$ & $\begin{array}{l}0.0392 * \\
(0.0218)\end{array}$ \\
\hline CEFTA & $\begin{array}{l}-0.0478 \\
(0.0305)\end{array}$ & $\begin{array}{l}-0.0412 \\
(0.0317)\end{array}$ & $\begin{array}{l}-0.0434 \\
(0.0307)\end{array}$ & $\begin{array}{l}0.000653 \\
(0.0155)\end{array}$ \\
\hline Voleuro & & $\begin{array}{l}0.121 \\
(0.217)\end{array}$ & & \\
\hline Vol EER & & & $\begin{array}{l}0.0287 \\
(0.459)\end{array}$ & \\
\hline Customs time & & & & $\begin{array}{l}0.000739 \\
(0.000781)\end{array}$ \\
\hline $\mathrm{N}$ & 4163 & 4112 & 4019 & 2862 \\
\hline Pseudo R-sq & 0.184 & 0.183 & 0.180 & 0.099 \\
\hline
\end{tabular}

Notes: Reported values are marginal effects at the mean of the independent variables; Robust standard errors clustered at the country and industry level in parentheses; ${ }^{* * *} \mathrm{p}<0.01,{ }^{* *} \mathrm{p}<0.05,{ }^{*} \mathrm{p}<0.1$. All columns include country dummies and industry and year dummies, not reported to save space. The dependent variable is binary $(0,1)$ and takes the value of one when a firm exports indirectly (broad definition: indirect exporters only + exporters with a mixed exporting strategy) and zero when a firm exports directly only. Retailers and wholesalers are excluded from the regressions.

Regression estimates of the model specified in equation (3), with the share of indirect exports as the dependent variable, are provided in Table 6. There are two main differences with respect to the results in Table 5. Firstly, the estimates for the variables firm size and labour productivity are statistically significant in Table 6 (columns 1-3), indicating that a 1-percent increase in firm size (labour productivity) is associated with a decrease in the share of indirect exports of around $0.3(0.5)$ percentage points. Nevertheless, the coefficient of firm size is only significant at the ten percent level in models (1) and (2). 
Table 6. Fractional Regression Results - Share of Indirect Exports

\begin{tabular}{|c|c|c|c|c|}
\hline Dep. Variable: & $\begin{array}{c}\text { (1) } \\
\text { Share of } \\
\text { Ind. Exports }\end{array}$ & $\begin{array}{c}\text { (2) } \\
\text { Share of } \\
\text { Ind. Exports }\end{array}$ & $\begin{array}{c}(3) \\
\text { Share of } \\
\text { Ind. Exports }\end{array}$ & $\begin{array}{c}\quad(4) \\
\text { Share of } \\
\text { Ind. Exports }\end{array}$ \\
\hline \multicolumn{5}{|l|}{ Ind. Variables: } \\
\hline Ln N Employees & $\begin{array}{c}-0.00360^{*} \\
(0.00196)\end{array}$ & $\begin{array}{l}-0.00378 * \\
(0.00199)\end{array}$ & $\begin{array}{l}-0.00331 \\
(0.00202)\end{array}$ & $\begin{array}{l}0.000509 \\
(0.00131)\end{array}$ \\
\hline Ln Labour Productivity & $\begin{array}{c}-0.00554 * * \\
(0.00231)\end{array}$ & $\begin{array}{c}-0.00577^{* *} \\
(0.00235)\end{array}$ & $\begin{array}{c}-0.00971^{* * * *} \\
(0.00263)\end{array}$ & $\begin{array}{l}-0.00130 \\
(0.00177)\end{array}$ \\
\hline Foreign & $\begin{array}{c}0.00362 \\
(0.00720)\end{array}$ & $\begin{array}{c}0.00473 \\
(0.00736)\end{array}$ & $\begin{array}{c}0.00484 \\
(0.00750)\end{array}$ & $\begin{array}{l}0.000827 \\
(0.00448)\end{array}$ \\
\hline Export Intensity & $\begin{array}{c}-0.00444^{* * *} \\
(0.000163)\end{array}$ & $\begin{array}{c}-0.00445^{* * *} \\
(0.000163)\end{array}$ & $\begin{array}{c}-0.00440 * * * \\
(0.000162)\end{array}$ & $\begin{array}{c}-0.000988^{* * *} \\
(8.53 \mathrm{e}-05)\end{array}$ \\
\hline Transport & $\begin{array}{c}0.0163 \\
(0.0140)\end{array}$ & $\begin{array}{c}0.0156 \\
(0.0143)\end{array}$ & $\begin{array}{c}0.0204 \\
(0.0150)\end{array}$ & $\begin{array}{c}0.0116 \\
(0.00952)\end{array}$ \\
\hline Customs & $\begin{array}{c}0.00231 \\
(0.00256)\end{array}$ & $\begin{array}{c}0.00223 \\
(0.00261)\end{array}$ & $\begin{array}{c}0.00175 \\
(0.00263)\end{array}$ & $\begin{array}{c}0.00245 \\
(0.00159)\end{array}$ \\
\hline Crime & $\begin{array}{c}0.00594 * * \\
(0.00257)\end{array}$ & $\begin{array}{c}0.00597 * * \\
(0.00262)\end{array}$ & $\begin{array}{c}0.00537 * * \\
(0.00265)\end{array}$ & $\begin{array}{c}0.00250 \\
(0.00172)\end{array}$ \\
\hline Legal System & $\begin{array}{l}-0.00436 \\
(0.00317)\end{array}$ & $\begin{array}{l}-0.00456 \\
(0.00322)\end{array}$ & $\begin{array}{l}-0.00443 \\
(0.00327)\end{array}$ & $\begin{array}{c}-0.00381^{*} \\
(0.00218)\end{array}$ \\
\hline $\mathrm{EU}$ & $\begin{array}{c}-0.0347^{* * *} \\
(0.0127)\end{array}$ & $\begin{array}{c}-0.0367 * * * \\
(0.0130)\end{array}$ & $\begin{array}{c}-0.0349 * * * \\
(0.0132)\end{array}$ & $\begin{array}{c}-0.0116 \\
(0.00875)\end{array}$ \\
\hline CEFTA & $\begin{array}{c}-0.0173 \\
(0.0149)\end{array}$ & $\begin{array}{l}-0.0133 \\
(0.0153)\end{array}$ & $\begin{array}{c}-0.0146 \\
(0.0151)\end{array}$ & $\begin{array}{l}-0.00941 \\
(0.00930)\end{array}$ \\
\hline Voleuro & & $\begin{array}{c}0.113 \\
(0.0812)\end{array}$ & & \\
\hline Vol EER & & & $\begin{array}{c}0.165 \\
(0.180)\end{array}$ & \\
\hline Customs Time & & & & $\begin{array}{c}0.000479 * * \\
(0.000223)\end{array}$ \\
\hline Observations & 4,250 & 4,195 & 4,104 & 3,004 \\
\hline Pseudo R-squared & 0.310 & 0.308 & 0.306 & 0.126 \\
\hline
\end{tabular}

Notes: Reported values are marginal effects at the mean of the independent variables; Robust standard errors in parentheses; ${ }^{* * *} \mathrm{p}<0.01,{ }^{* *} \mathrm{p}<0.05,{ }^{*} \mathrm{p}<0.1$. All columns include country dummies and industry-year dummies, not reported to save space. Retailers and wholesalers are excluded from the regressions.

Secondly, only one of the variables representing the fixed cost of exporting, or more generally uncertainty, is statistically significant, namely crime, theft and disorder. Legal system is also statistically significant in column (4) but only at the ten percent level. Finally, 
in column (4), when the time to clear customs is added, the effect significant at the five percent level, but the effect is negligible in economic terms.

\subsection{Goods versus Services}

The dataset used in this study covers firms producing goods and others providing services, and the two types of firms differ significantly in terms of export procedures. For this reason, we present in this section separate estimates for goods and services, which enables us to analyse the differences between these two sets of exporters in terms of the impact of perceived uncertainty on the decision to export indirectly.

In order to be able to compare the estimates, we estimate the models (1) and (3) separately for goods and services, with the same specifications as in column (2) and (3) in Tables 5 and Table 6. Table 7 shows the estimation results for the probit model (1), whereas the results for the intensity of indirect exports (model (3)) are shown in Table 8. The tables are divided into two parts: the first shows the results for goods and the second for services excluding retailers and wholesalers.

According to the results shown in Table 7, the three variables used as proxies for fixed cost of exporting, namely transport, customs and trade regulations and crime, all appear to significantly increase the probability of exporting goods indirectly, but this is not the case for the service sector. For the latter sector, it is only the variable business permits and licences as an obstacle to current operations of the firm that was found to affect the response variable.

Moreover, foreign ownership encourages indirect exports for services. It is also in the services sector that smaller exporters are likely to export more indirectly. Meanwhile, less productive firms in the goods sector are likely to export more indirectly.

Concerning the country-specific variables, the effect of volatility in the exchange rate increases the probability of indirect exports for services, but decreases it for goods. With 
regard to regional integration, EU and CEFTA membership affect the probability of indirect exporting mainly in the goods sector, but not in the services sector.

Table 8 shows in columns (1) and (2) that perception of crime as an obstacle and customs and trade regulations have also a significant impact on the share of indirect exports of goods, but the magnitude of the effects are halved; whereas transportation as an obstacle is not statistically significant in Table 8. EU membership also reduces indirect export intensity for goods but not for services (columns (3) and (4) in Table 8). Volatility of the exchange rate is not affecting the intensity of indirect exporting in the goods sector. However, it does affect the service sector to a lesser extent than in Table 7, where the dependent variable was the decision to export indirectly.

Summarizing, the determinants of the probability of exporting indirectly and the intensity of indirect exports differ to some extent for goods and services. On the one hand, a higher perception of crime as an obstacle appears to affect positively the decision to export goods indirectly but does not affect services. On the other hand, firms are more likely to export services indirectly as firm size decreases, when firms are not foreign owned and when uncertainty surrounding future revenues due to domestic exchange rate volatility rises. The first outcome seems intuitive when considering crime in the form of physical theft of goods, while the latter could be due to distinctive characteristics of the service sector in general that make it more vulnerable to fluctuations in the exchange rate. Reasons for these findings could include an infrequent use of indirect hedging, with fewer inputs needed in the production process of services than of goods and/or more restricted access to financial hedging due to a lack of assets. Furthermore, more severe transportation obstacles increase the probability of exporting indirectly, though this is true for firms in the goods sector only. A likely explanation for this is that services are frequently non-tradable goods that often need to be provided close to where the customer is based, and are therefore not affected by obstacles 
related to the transportation of goods, supplies and inputs. From the firm's perspective, these obstacles do increase the fixed costs of exporting and thereby affect their decision to export but since indirect exporters do not have to deal directly with the transportation of goods, they do not have to perceive transportation as a serious obstacle.

Table 7. Probit Results - Goods versus Services exports

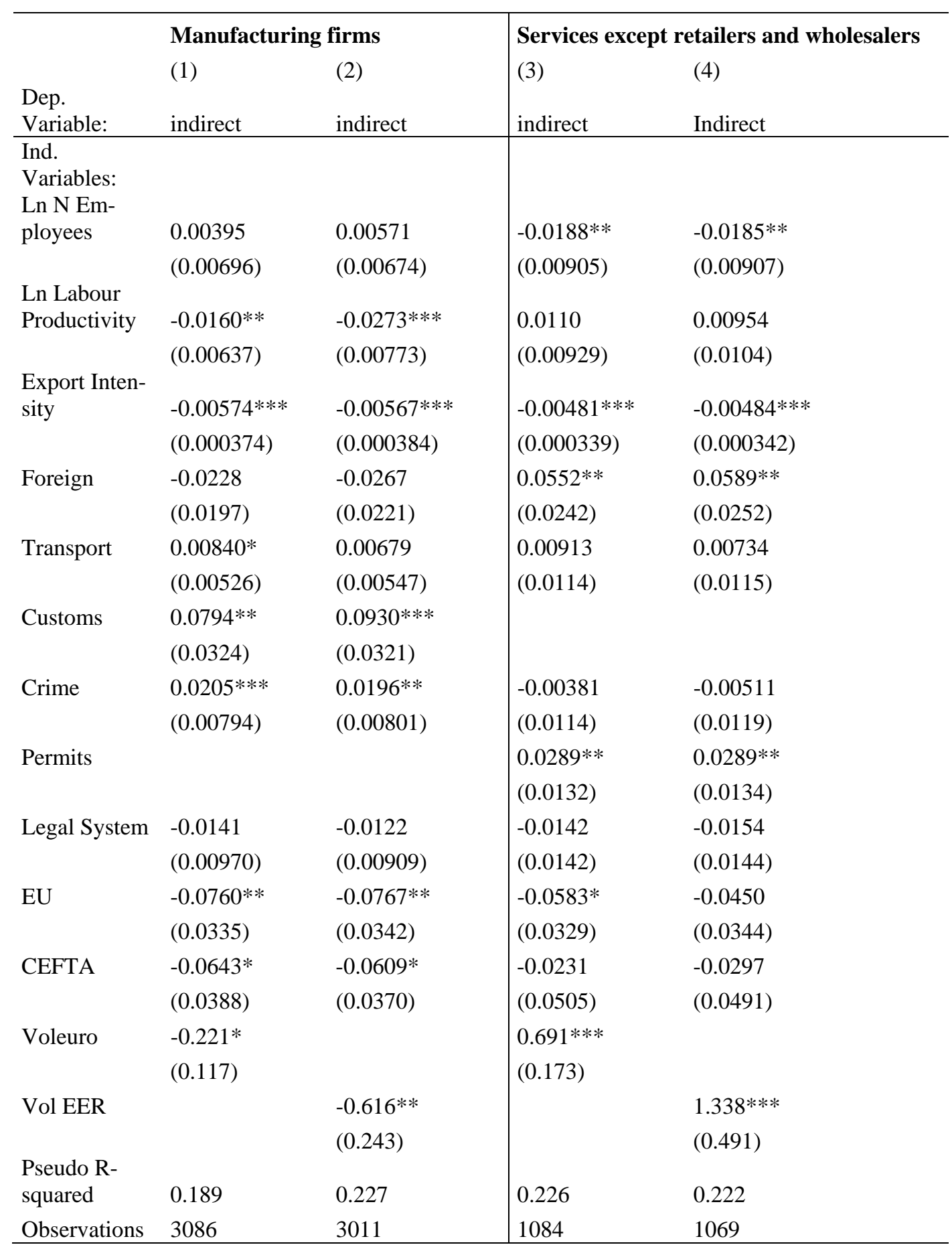


Notes: Reported values are marginal effects at the mean of the independent variables; Robust standard errors clustered at the country and industry level in parentheses; ${ }^{* * *} \mathrm{p}<0.01,{ }^{* *} \mathrm{p}<0.05,{ }^{*} \mathrm{p}<0.1$. All columns include country dummies and industry and year dummies, not reported to save space. The dependent variable is binary $(0,1)$ and takes the value of one when a firm exports indirectly (broad definition: indirect exporters only + exporters with a mixed exporting strategy). Retailers and wholesalers are excluded from the regressions.

Table 8. Fractional probit Results - Goods versus Services exports

\begin{tabular}{|c|c|c|c|c|}
\hline \multirow[b]{2}{*}{ Dep.variable: } & \multicolumn{2}{|c|}{$\begin{array}{l}(1) \\
\text { Manufacturing firms }\end{array}$} & \multicolumn{2}{|c|}{\begin{tabular}{|c|}
$(3)$ \\
Services except retailers and wholesalers
\end{tabular}} \\
\hline & indirectshare & indirectshare & indirectshare & Indirectshare \\
\hline Ind. Variables: & & & & \\
\hline Ln N Employees & $\begin{array}{l}-0.000279 \\
(0.00248)\end{array}$ & $\begin{array}{l}0.000590 \\
(0.00251)\end{array}$ & $\begin{array}{c}-0.00852 * * * \\
(0.00296)\end{array}$ & $\begin{array}{c}-0.00846 * * * \\
(0.00298)\end{array}$ \\
\hline $\begin{array}{l}\text { Ln Labour Produc- } \\
\text { tivity }\end{array}$ & $\begin{array}{c}-0.00872 * * * \\
(0.00286)\end{array}$ & $\begin{array}{c}-0.0143 * * * \\
(0.00320)\end{array}$ & $\begin{array}{l}0.000400 \\
(0.00399)\end{array}$ & $\begin{array}{l}-0.000649 \\
(0.00430)\end{array}$ \\
\hline Foreign & $\begin{array}{l}-0.00773 \\
(0.00828)\end{array}$ & $\begin{array}{l}-0.00910 \\
(0.00829)\end{array}$ & $\begin{array}{l}0.0264 * \\
(0.0138)\end{array}$ & $\begin{array}{l}0.0290 * * \\
(0.0143)\end{array}$ \\
\hline Export Intensity & $\begin{array}{c}-0.00459 * * * \\
(0.000190)\end{array}$ & $\begin{array}{c}-0.00451^{* * * *} \\
(0.000189)\end{array}$ & $\begin{array}{c}-0.00379 * * * \\
(0.000351)\end{array}$ & $\begin{array}{c}-0.00383 * * * \\
(0.000343)\end{array}$ \\
\hline Transport & $\begin{array}{l}-4.22 \mathrm{e}-05 \\
(0.00306)\end{array}$ & $\begin{array}{l}-0.000573 \\
(0.00308)\end{array}$ & $\begin{array}{c}0.00362 \\
(0.00456)\end{array}$ & $\begin{array}{c}0.00272 \\
(0.00464)\end{array}$ \\
\hline Crime & $\begin{array}{c}0.00939 * * * \\
(0.00315)\end{array}$ & $\begin{array}{c}0.00888 * * * \\
(0.00317)\end{array}$ & $\begin{array}{l}-0.00201 \\
(0.00435)\end{array}$ & $\begin{array}{l}-0.00283 \\
(0.00443)\end{array}$ \\
\hline Legal System & $\begin{array}{l}-0.00486 \\
(0.00383)\end{array}$ & $\begin{array}{l}-0.00452 \\
(0.00387)\end{array}$ & $\begin{array}{l}-0.00503 \\
(0.00553)\end{array}$ & $\begin{array}{l}-0.00589 \\
(0.00562)\end{array}$ \\
\hline EU & $\begin{array}{c}-0.0415 * * \\
(0.0164)\end{array}$ & $\begin{array}{c}-0.0409 * * \\
(0.0165)\end{array}$ & $\begin{array}{l}-0.0204 \\
(0.0186)\end{array}$ & $\begin{array}{l}-0.0136 \\
(0.0195)\end{array}$ \\
\hline CEFTA & $\begin{array}{l}-0.0228 \\
(0.0193)\end{array}$ & $\begin{array}{l}-0.0214 \\
(0.0189)\end{array}$ & $\begin{array}{l}-0.00409 \\
(0.0216)\end{array}$ & $\begin{array}{l}-0.00629 \\
(0.0219)\end{array}$ \\
\hline Customs & $\begin{array}{l}0.0327 * \\
(0.0185)\end{array}$ & $\begin{array}{c}0.0418 * * \\
(0.0197)\end{array}$ & & \\
\hline Permits & & & $\begin{array}{l}0.0100 * * \\
(0.00464)\end{array}$ & $\begin{array}{l}0.0102 * * \\
(0.00467)\end{array}$ \\
\hline Voleuro & $\begin{array}{l}-0.0277 \\
(0.109)\end{array}$ & & $\begin{array}{l}0.260 * * \\
(0.104)\end{array}$ & \\
\hline Vol EER & & $\begin{array}{l}-0.122 \\
(0.229)\end{array}$ & & $\begin{array}{c}0.502 * * \\
(0.243)\end{array}$ \\
\hline Observations & 3,086 & 3,011 & 1,087 & 1,071 \\
\hline Pseudo R-squared & 0.309 & 0.308 & 0.346 & 0.345 \\
\hline
\end{tabular}

Notes: Reported values are marginal effects at the mean of the independent variables; Robust standard errors in parentheses; $* * * \mathrm{p}<0.01, * * \mathrm{p}<0.05, * \mathrm{p}<0.1$. All columns include country dummies and industry and year dummies, not reported to save space. Retailers and wholesalers are excluded from the regressions.

\subsection{Robustness}


As a first robustness check we estimated a Heckman-Probit and a fractional regression with correction for selection bias. The Heckman-Probit involves two equations that use the probability of exporting or not and the probability of exporting indirectly, respectively, as dependent variables, and the second stage uses the share of indirect exports.

Table A.4 shows in columns (1) and (2) the first and second step from the Heckman-Probit and in column (3) the fractional Probit second step results. A Wald test of independence of equations (1) and (2) indicates that we cannot reject the null hypothesis of independence between the decision to export and the decision to export indirectly. Moreover, the Mills ratio in the second step regression is not statistically significant, indicating that the intensity of indirect exporting is independent from the decision of how to export. Concerning the reported estimates, in general the sign of variation is similar as in Tables 5 and 6, but most estimates lose precision.

Results in column (2) indicate that while a higher number of employees, labour productivity and foreign ownership lead to an increase in a firm's probability of exporting, a more acute perception of crime and customs as obstacles decreases the probability of exporting and increases the share of intermediated exports. As previously explained, we exclude the variable corruption from the Probit in column (1) to fulfil the exclusion restriction.

EU membership, but not CEFTA membership, has a significant positive impact on the probability of exporting. EU and CEFTA membership, however, negatively affect the share of intermediated exports. The fact that the IMR from the Heckman-Probit is not significant in the second stage suggests that there is no evidence of a selection bias coming from the decision on the export mode.

As a second robustness check we use the narrow definition of indirect exports and estimate the same models as in the previous section in Table 5. The results are presented in Table A.5, 
which includes probit estimations in columns (1) to (3). The main difference found compared to the previous results is that the exchange rate volatility variable is now statistically significant, indicating that higher levels of volatility increase a firm's probability of exporting indirectly only. Firm size and labour productivity are also now statistically significant; smaller and less productive firms are more likely to export only indirectly than to pursue a mixed exporting strategy or export only directly. Also, foreign ownership decreases the probability of selecting the indirect-only exporting strategy. Comparing the variables transportation and crime with the previous results, only the second stays statistically significant. Hence, transportation of goods, supplies and inputs does not seem to increase the likelihood of exporting only indirectly. The main drawback of using this definition is the low number of firms that only export indirectly, around 700, which makes unfeasible a separate analysis for goods and services.

\section{Conclusions}

Although it is by its very nature vague, uncertainty, measured as the perceived severity of obstacles, appears to play an important role in explaining a firm's choice between direct and indirect exporting. It also seems to have a different impact on goods and services.

Firms that are smaller, less productive and that export a lower share of their production prefer indirect exporting over direct exporting, while uncertainty in different fields makes the use of intermediaries increasingly attractive to firms. In particular, the perception of potential threats such as criminality and problems with customs and transport infrastructure has a significant impact on the mode of export, favouring indirect exporting versus direct exporting. Furthermore, we show that uncertainty about future revenues due to volatility in the domestic exchange rate favours indirect exporting and increases the share of indirect exports over total exports of services, but decreases that of goods. We were also able to show that the main 
results are not driven by sample selection bias, and the inclusion of various controls confirms their robustness.

A limitation of the paper is that the lack of panel data does not allow us to control for unobserved heterogeneity. Therefore, we are assuming that unobserved factors that are firmspecific are not correlated with the target variables used as proxies for business obstacles.

Finally, our findings highlight the importance of intermediaries in countries where firms perceive challenges in the business environment that affect the level of uncertainty and thus the fixed costs of exporting. Reducing perceived uncertainty as well as improving conditions for intermediaries would help domestic firms with their exporting activities. 


\section{References}

Abel-Koch, J., 2013. Who uses intermediaries in international trade? Evidence from firm-level survey data. The World Economy, 36(8), pp. 1041-1064.

Ahn, J., Khandelwal, A.K. and Wei, S.-J., 2011. The role of intermediaries in facilitating trade. Journal of International Economics, 84 (1), pp. 73-85.

Akerman, A., 2014. A Theory on the Role of Wholesalers in International Trade based on Economies of Scope. Research Papers in Economics, 1.

Bernard, A.B. et al., 2003. Plants and Productivity in International Trade. American Economic Review, 93(4), pp. 1268-1290.

Bernard, A.B., Grazzi, M. and Tomasi, C., 2015. Intermediaries in International Trade: Products and Destinations. The Review of Economics and Statistics 97 (4), pp. 916-920.

Bernard, A.B. and Jensen, J.B., 2004. Why Some Firms Export. The Review of Economics and Statistics, 86 (2), pp. 561-569.

Biglaiser, G., 1993. Middlemen as Experts. RAND Journal of Economics, 24 (2), pp. 212-223.

Crozet, M., Lalanne, G. and Poncet, S., 2013. Wholesalers in international trade. European Economic Review, 58, pp. 1-17.

Darvas, Z., 2012. Real effective exchange rates for 178 countries: A new database. Working Paper 2012/06, Bruegel, 15 March 2012. http://www.bruegel.org/publications/publicationdetail/publication/716-real-effective-exchange-rates-for-178-countries-a-new-database/.

De Groot, H. and Linders, G. J. et al., .2004. The institutional determinants of bilateral trade patterns. Kyklos, 57 (1), pp. 103-124.

Felbermayr, G. and Jung, B., 2011. Trade Intermediation and the Organization of Exporters. Review of International Economics, 19 (4), pp. 634-648.

Helpman, E., Melitz, M. and Rubinstein, Y., 2008. Estimating Trade Flows: Trading Partners and Trading Volumes. The Quarterly Journal of Economics, 123 (2), pp. 441-487.

McCann, F., 2013. Indirect Exporters. Journal of Industry, Competition and Trade, 13 (4), pp. 519535. 
Melitz, M.J., 2003. The Impact of Trade on Intra-Industry Reallocations and Aggregate Industry Productivity. Econometrica, 71 (6), pp. 1695 - 1725.

Oberhofer, H. and Pfaffermayr, M. 2012. Fractional Response Models - A Replication Exercise of Papke and Wooldridge (1996). Contemporary Economics, 6 (3), pp.56-64.

Papke, L. E, and Wooldridge, J. M. 1996. Econometric methods for fractional response variables with an application to 401(k) plan participation rates. Journal of Applied Econometrics, 11(6), pp. 619-632.

Roodman, D. (2011). Estimating Fully Observed Recursive Mixed-Process Models with cmp. Stata Journal, 11, 159-206.

Roodman, D., \& Morduch, J. (2011). The Impact of Microcredit on the Poor in Bangladesh: Revisiting the Evidence. Journal of Development Studies, 50 (4), pp. 583-604.

Rubinstein, A. and Wolinsky, A., 1987. Middlemen. The Quarterly Journal of Economics, 102 (3), pp. 581-93.

Spulber, D.F., 1999. Market Microstructure, Cambridge University Press.

Zerihun, S., 2012. A Firm’s Choice Between Direct and Indirect Export Channel of Exports by: A Study of Manufacturing Firms in Sub Saharan African Economies. Available at SSRN 2167982. 


\section{APPENDIX}

\section{Table A.1. Variables description}

Note: The subscripts i, j, k, t denote firm, country, sector and year, respectively. *Firms responded to the question: What

\begin{tabular}{|c|c|c|}
\hline Variable & Description & Range \\
\hline \multicolumn{3}{|l|}{ Dependent variable } \\
\hline Indirectexportsijkt & Share of indirect exports over total exports* & $0-100$ \\
\hline \multicolumn{3}{|c|}{ Firm characteristics } \\
\hline In Employees ijkt $_{\text {. }}$ & $\begin{array}{l}\text { Natural logarithm of the number of permanent full-time } \\
\text { workers }\end{array}$ & $0-10.54$ \\
\hline ln LaborProd ${ }_{\mathrm{ijkt}}$ & Natural logarithm of sales divided by the number of workers & $1.56-26.84$ \\
\hline Exportintensity $_{\mathrm{ijkt}}$ & Share of exported sales & $1-100$ \\
\hline Foreign $_{\mathrm{ijkt}}$ & $=1$ if part of the firm is owned by foreign private individuals & 0,1 \\
\hline Transportation $_{\mathrm{ijkt}}$ & $\begin{array}{l}\text { Perception of transportation of goods, supplies and inputs as } \\
\text { an obstacle }\end{array}$ & $0=$ no obstacle $-4=$ very severe \\
\hline Customs $_{\text {ijkt }}$ & Perception of customs and trade regulation as an obstacle & $\begin{array}{l}0=\text { no-moderate obstacle }-1=\text { Major } \\
\text { or very severe obstacle }\end{array}$ \\
\hline Crime $_{\mathrm{ijkt}}$ & Perception of crime, theft and disorder as an obstacle & $0=$ no obstacle $-4=$ very severe \\
\hline Legalsystem $_{\mathrm{ijkt}}$ & $\begin{array}{l}\text { Perception of the court system as fair, impartial and not cor- } \\
\text { rupt (Alternative measure: Perception of courts as an obsta- } \\
\text { cle for the current operations of the firm) }\end{array}$ & $\begin{array}{l}1=\text { agree }-4=\text { strongly disagree } \\
(0=\text { no obstacle }-4=\text { very severe })\end{array}$ \\
\hline Permits $_{\mathrm{ijkt}}$ & Perception of business permits and licences as an obstacle & $0=$ no obstacle $-4=$ very severe \\
\hline Customstime $_{\mathrm{ijkt}}$ & Av. number days it took for exported goods to clear customs & $1=1$ or fewer $-5=$ more than 20 \\
\hline \multicolumn{3}{|l|}{ Country variables } \\
\hline$E U_{j t}$ & $=1$ if country $\mathrm{j}$ was a member of the EU in year $\mathrm{t}$ & 0,1 \\
\hline CEFTA $_{\mathrm{jt}}$ & $=1$ if country $\mathrm{j}$ was a member of the CEFTA in year $\mathrm{t}$ & 0,1 \\
\hline VolatilityEuro $_{\mathrm{jt}-1}$ & $\begin{array}{l}\text { Measure of volatility in the exchange rate of } j \text { and the euro in } \\
t-1\end{array}$ & $0-0.47$ \\
\hline VolatilityEER $_{\mathrm{jt}-1}$ & $\begin{array}{l}\text { Measure of volatility in the nominal effective exchange rate } \\
\text { of } \mathrm{j} \text { and } 138 \text { countries in } \mathrm{t}-1\end{array}$ & $0.002-0.196$ \\
\hline
\end{tabular}

percentage of establishment sales were: national sales, indirect exports (sales through a third party); direct exports?” 
Table A.2 Share of firms in each sector by export status

\begin{tabular}{|c|c|c|c|c|c|c|}
\hline code & $\underline{\text { Sector }}$ & $\begin{array}{l}\text { Non- } \\
\text { exporter }\end{array}$ & $\begin{array}{l}\text { Indirect } \\
\underline{\text { only }}\end{array}$ & $\frac{\text { Ind and }}{\text { Direct }}$ & $\begin{array}{l}\text { Direct } \\
\text { only }\end{array}$ & $\frac{\text { Total }}{1,651}$ \\
\hline 2 & Other manufacturing & 59.1 & 5.6 & 6.5 & 28.7 & \\
\hline 15 & Food & 64.5 & 4.2 & 4.4 & 26.9 & 3,771 \\
\hline 17 & Textiles & 47.6 & 8.6 & 5.0 & 38.8 & 361 \\
\hline 18 & Garments & 59.9 & 6.5 & 5.1 & 28.5 & 1,200 \\
\hline 24 & Chemicals & 49.4 & 6.1 & 6.7 & 37.7 & 342 \\
\hline 25 & Plastics and rubber & 52.8 & 5.2 & 9.3 & 32.7 & 248 \\
\hline 26 & Non metallic minerals & 65.1 & 2.3 & 4.7 & 27.9 & 344 \\
\hline 27 & Basic metals & 48.6 & 4.9 & 7.0 & 39.4 & 142 \\
\hline 28 & Fabricated metal prod. & 57.2 & 4.8 & 6.1 & 31.9 & 1,174 \\
\hline 29 & Machinery and equipment & 47.6 & 5.7 & 7.6 & 39.1 & 955 \\
\hline \multirow[t]{2}{*}{31} & Electronics (31 and 32) & 48.7 & 5.6 & 5.6 & 40.1 & 197 \\
\hline & Manufacturing & 58.9 & 5.1 & 5.6 & 30.4 & 10385 \\
\hline 45 & Construction Section & 89.5 & 1.2 & 0.9 & 8.5 & 2,693 \\
\hline 50 & Other services & 84.2 & 1.5 & 1.4 & 12.9 & 2,779 \\
\hline 51 & Wholesale & 78.1 & 3.0 & 2.4 & 16.6 & 3,488 \\
\hline 52 & Retail & 91.7 & 1.5 & 1.1 & 5.7 & 4,179 \\
\hline 55 & Hotel and restaurants & 86.4 & 2.7 & 2.3 & 8.6 & 1,318 \\
\hline 60 & Transport Section & 60.2 & 5.2 & 5.9 & 28.6 & 1,682 \\
\hline \multirow[t]{3}{*}{72} & IT & 62.2 & 1.9 & 2.2 & 33.8 & 370 \\
\hline & Services & 82.9 & 2.2 & 2.0 & 12.9 & 16,509 \\
\hline & Total & 73.6 & 3.4 & 3.4 & 19.6 & 26,894 \\
\hline
\end{tabular}

Note: Last column reports number of firms per sector, the rest report percentages. 
Table A.3 Number of firms by country and sector

\begin{tabular}{|c|c|c|c|c|c|c|c|c|c|c|c|c|c|c|c|c|c|c|}
\hline \multirow[b]{2}{*}{ Country: } & \multicolumn{18}{|c|}{ Sector: } \\
\hline & 2 & 15 & 17 & 18 & 24 & 25 & 26 & 27 & 28 & 29 & 45 & 50 & 51 & 52 & 55 & 60 & 72 & Total \\
\hline Albania & 31 & 88 & 33 & 11 & 9 & 6 & 14 & 10 & 23 & 1 & 74 & 68 & 119 & 88 & 88 & 67 & 1 & 733 \\
\hline Armenia & 65 & 215 & 8 & 28 & 15 & 8 & 17 & 7 & 34 & 13 & 53 & 61 & 73 & 164 & 68 & 48 & 15 & 896 \\
\hline Azerbaijan & 36 & 185 & 43 & 3 & 9 & 6 & 17 & 29 & 6 & 43 & 93 & 65 & 111 & 159 & 36 & 43 & 6 & 900 \\
\hline Belarus & 50 & 63 & 11 & 18 & 11 & 11 & 12 & 1 & 17 & 7 & 168 & 83 & 150 & 149 & 16 & 69 & 12 & 848 \\
\hline Bosnia & 80 & 108 & 6 & 9 & 4 & 12 & 5 & 3 & 28 & 13 & 70 & 47 & 134 & 130 & 46 & 43 & 2 & 743 \\
\hline Bulgaria & 76 & 233 & 24 & 163 & 48 & 27 & 19 & 1 & 76 & 108 & 82 & 115 & 190 & 292 & 72 & 86 & 167 & 1,854 \\
\hline $\begin{array}{l}\text { Croatia } \\
\text { Czech }\end{array}$ & 85 & 181 & 33 & 56 & 7 & 18 & 17 & 2 & 126 & 26 & 99 & 82 & 149 & 163 & 46 & 46 & 10 & 1,162 \\
\hline Republic & 54 & 93 & 4 & 4 & 9 & 15 & 9 & 10 & 27 & 31 & 109 & 123 & 104 & 117 & 60 & 72 & 12 & 862 \\
\hline Estonia & 65 & 47 & 5 & 14 & 2 & 4 & 7 & 1 & 13 & 7 & 85 & 94 & 71 & 123 & 63 & 51 & r & 662 \\
\hline FYROM & 44 & 94 & 7 & 36 & 6 & 2 & 9 & 6 & 16 & 5 & 72 & 44 & 147 & 135 & 48 & 54 & 6 & 736 \\
\hline Georgia & 47 & 109 & 3 & 4 & 3 & 6 & 17 & 11 & 7 & 3 & 75 & 96 & 79 & 168 & 57 & 60 & 2 & 747 \\
\hline Hungary & 61 & 132 & 8 & 58 & 6 & 13 & 9 & 7 & 149 & 85 & 107 & 122 & 153 & 120 & 47 & 54 & 13 & 1,151 \\
\hline Kazakhstan & 84 & 273 & 6 & 82 & 5 & 10 & 19 & 2 & 42 & 71 & 170 & 119 & 156 & 226 & 37 & 61 & 7 & 1,380 \\
\hline Kyrgyz & 46 & 110 & 17 & 3 & 4 & 6 & 10 & 4 & 3 & 7 & 75 & 71 & 89 & 82 & 25 & 51 & 2 & 610 \\
\hline Latvia & 58 & 53 & 6 & 12 & 0 & 1 & 5 & 2 & 8 & 6 & 53 & 90 & 124 & 152 & 28 & 50 & 3 & 652 \\
\hline Lithuania & 66 & 65 & 14 & 13 & 1 & 6 & 6 & 0 & 7 & 11 & 87 & 63 & 81 & 114 & 63 & 72 & 5 & 682 \\
\hline Moldova & 36 & 212 & 2 & 47 & 5 & 2 & 7 & 0 & 48 & 5 & 53 & 76 & 115 & 194 & 29 & 55 & 0 & 887 \\
\hline Montenegro & 13 & 24 & 1 & 0 & 2 & 0 & 1 & 0 & 5 & 1 & 7 & 6 & 24 & 47 & 12 & 10 & 1 & 154 \\
\hline Poland & 73 & 227 & 15 & 162 & 6 & 20 & 23 & 4 & 184 & 82 & 212 & 189 & 273 & 242 & 50 & 144 & 19 & 1,930 \\
\hline Romania & 69 & 227 & 12 & 119 & 16 & 10 & 10 & 7 & 110 & 67 & 111 & 134 & 121 & 235 & 55 & 78 & 9 & 1,396 \\
\hline Russia & 152 & 302 & 17 & 126 & 103 & 22 & 27 & 12 & 100 & 121 & 225 & 256 & 245 & 215 & 54 & 103 & 10 & 2,114 \\
\hline Serbia & 67 & 108 & 17 & 9 & 14 & 12 & 8 & 4 & 30 & 13 & 82 & 121 & 148 & 135 & 50 & 67 & 9 & 900 \\
\hline Slovakia & 30 & 46 & 5 & 6 & 9 & 4 & 5 & 4 & 23 & 23 & 69 & 135 & 97 & 106 & 44 & 42 & 13 & 665 \\
\hline Slovenia & 34 & 59 & 11 & 4 & 7 & 13 & 10 & 3 & 33 & 30 & 94 & 107 & 88 & 90 & 42 & 47 & 11 & 687 \\
\hline Tajikistan & 37 & 102 & 25 & 18 & 6 & 3 & 22 & 2 & 5 & 8 & 99 & 84 & 104 & 127 & 35 & 52 & 1 & 736 \\
\hline Ukraine & 156 & 310 & 14 & 179 & 18 & 6 & 18 & 6 & 47 & 146 & 154 & 248 & 212 & 204 & 84 & 82 & 20 & 1,908 \\
\hline Uzbekistan & 36 & 105 & 14 & 16 & 17 & 5 & 21 & 4 & 7 & 22 & 115 & 80 & 131 & 202 & 63 & 75 & 7 & 926 \\
\hline Total in 1000 & 1.7 & 3.8 & 0.4 & 1.2 & 0.3 & 0.2 & 0.3 & 0.1 & 1.2 & 1 & 2.7 & 2.8 & 3.5 & 4.2 & 1.3 & 1.7 & 0.4 & 26.697 \\
\hline
\end{tabular}

Notes: Sectors 45-72 are services. Sectors 51 and 52 are, respectively, wholesalers and retailers. 
Table A.4. Heckman-Probit model and second-step fractional probit

\begin{tabular}{|c|c|c|c|}
\hline \multicolumn{4}{|c|}{ Heckman Probit } \\
\hline Dep. Var: & $\begin{array}{c}\text { (1) } \\
\text { Probit_indirect }\end{array}$ & $\begin{array}{c}\text { (2) } \\
\text { Probit_exporting } \\
\text { Select (export) }\end{array}$ & $\begin{array}{l}\text { (3) } \\
\text { Fractional Probit } \\
\text { Indirect share }\end{array}$ \\
\hline Ind. Variables: & & & \\
\hline Ln N Employees & $\begin{array}{l}-0.0908 \\
(0.0759)\end{array}$ & $\begin{array}{l}0.264^{* * *} \\
(0.00974)\end{array}$ & $\begin{array}{c}-0.00184 \\
(0.00671)\end{array}$ \\
\hline Ln Labour Productivity & $\begin{array}{l}-0.0311 \\
(0.0277)\end{array}$ & $\begin{array}{c}0.0772 * * * \\
(0.0112)\end{array}$ & $\begin{array}{c}0.00186 \\
(0.00347)\end{array}$ \\
\hline Foreign & $\begin{array}{c}-0.316^{* *} \\
(0.159)\end{array}$ & $\begin{array}{c}0.647 * * * \\
(0.0392)\end{array}$ & $\begin{array}{l}-0.0348 \\
(0.0243)\end{array}$ \\
\hline Customs & $\begin{array}{c}0.362 * * \\
(0.147)\end{array}$ & $\begin{array}{c}-0.488^{* * *} \\
(0.0551)\end{array}$ & $\begin{array}{c}0.0119 * \\
(0.00650)\end{array}$ \\
\hline Transport & $\begin{array}{c}0.0341 \\
(0.0262)\end{array}$ & $\begin{array}{c}0.0166 \\
(0.0133)\end{array}$ & $\begin{array}{l}0.00365 \\
(0.0364)\end{array}$ \\
\hline Crime & $\begin{array}{c}0.0551 * * \\
(0.0247)\end{array}$ & $\begin{array}{c}-0.0664 * * * \\
(0.0139)\end{array}$ & $\begin{array}{c}0.00853 \\
(0.00674)\end{array}$ \\
\hline Corruption & & $\begin{array}{c}0.0423^{* * *} \\
(0.0123)\end{array}$ & \\
\hline Legal System & $\begin{array}{c}-0.0624 * * \\
(0.0283)\end{array}$ & $\begin{array}{c}0.0147 \\
(0.0161)\end{array}$ & $\begin{array}{l}0.000715 \\
(0.00626)\end{array}$ \\
\hline EU & $\begin{array}{l}-0.138 \\
(0.126)\end{array}$ & $\begin{array}{l}0.144 * * \\
(0.0693)\end{array}$ & $\begin{array}{l}-0.0226 * \\
(0.0120)\end{array}$ \\
\hline CEFTA & $\begin{array}{l}-0.161 \\
(0.131)\end{array}$ & $\begin{array}{c}0.0276 \\
(0.0794)\end{array}$ & $\begin{array}{c}-0.0283^{* *} \\
(0.0139)\end{array}$ \\
\hline Voleuro & $\begin{array}{l}-0.366 \\
(1.036)\end{array}$ & $\begin{array}{l}-0.839 * \\
(0.478)\end{array}$ & $\begin{array}{l}-0.0806 \\
(0.159)\end{array}$ \\
\hline IMR & & & $\begin{array}{l}-0.0204 \\
(0.052)\end{array}$ \\
\hline Pseudo R-squared & 0.255 & & \\
\hline Observations & 12,173 & 12,173 & 4056 \\
\hline Censored Observations & & 8618 & \\
\hline Rho & -0.541 & -0.541 & \\
\hline Probability & 0.225 & 0.225 & \\
\hline
\end{tabular}

Note: Reported values are marginal effect at the mean values of the independent variables; Robust standard errors in parentheses. ${ }^{* * *} \mathrm{p}<0.01,{ }^{* *} \mathrm{p}<0.05$, ${ }^{*} \mathrm{p}<0.1$. IMR denotes the inverse Mills ratio from the Heckman-Probit main equation. Rho is a Wald test of independent equations in the Heckman-Probit model and the associated probability of rejecting the null hypothesis of independence is reported in the last row of the table. 
Table A.5. Narrow definition of indirect exports

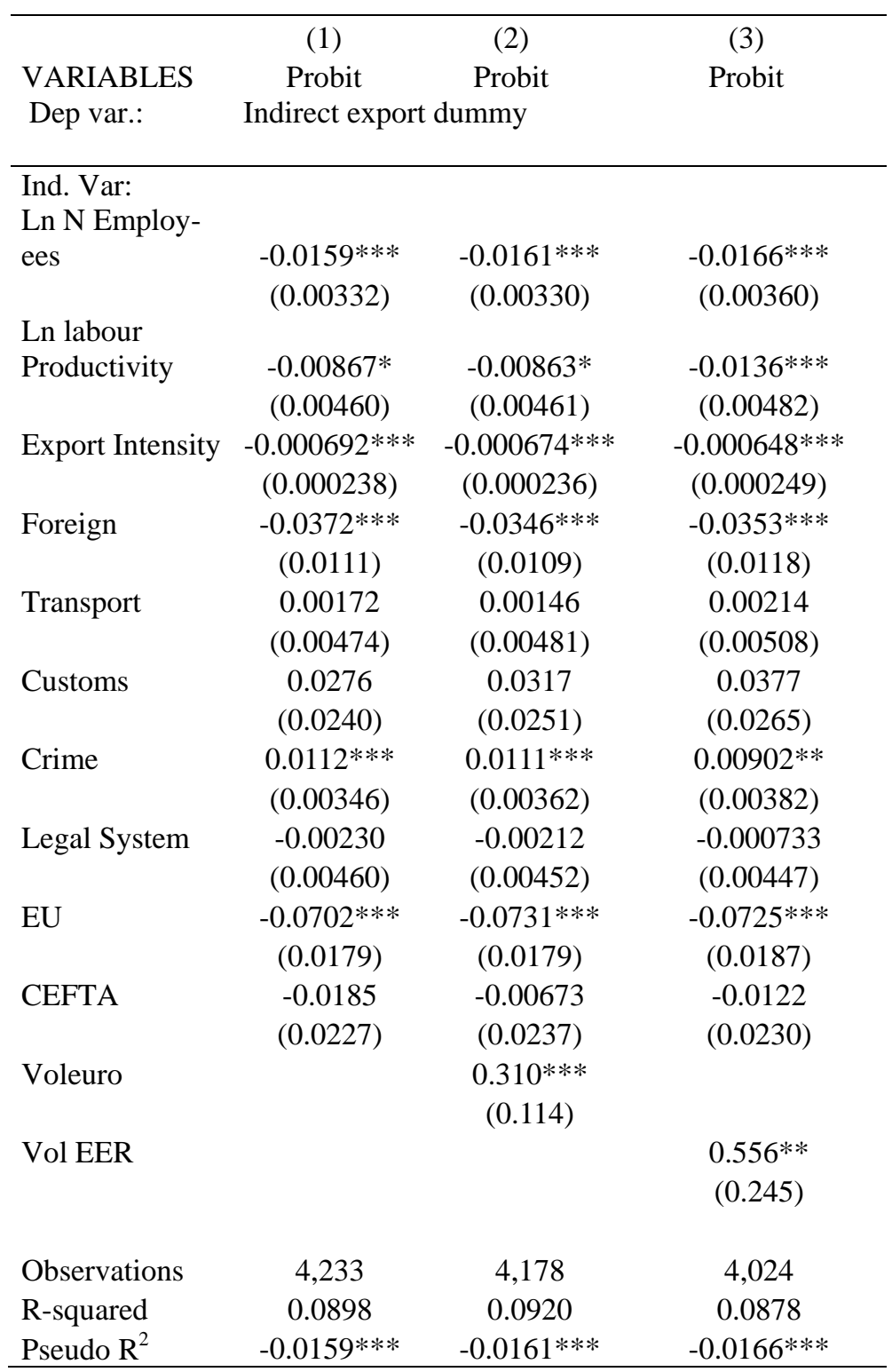

Notes: Reported values are marginal effects of the independent variables; Robust standard errors clustered at the country and industry level in parentheses; ${ }^{* *} \mathrm{p}<0.01, * * \mathrm{p}<0.05, * \mathrm{p}<0.1$. All columns include country dummies and industry and year dummies, not reported to save space. The dependent variable is binary $(0,1)$ and takes the value of one when a firm exports indirectly (narrow definition: indirect exporters only). Retailers and wholesalers are excluded from the regressions. 
Figure A.1 Labour productivity distribution for direct and indirect exporters and non-exporters, whole sample

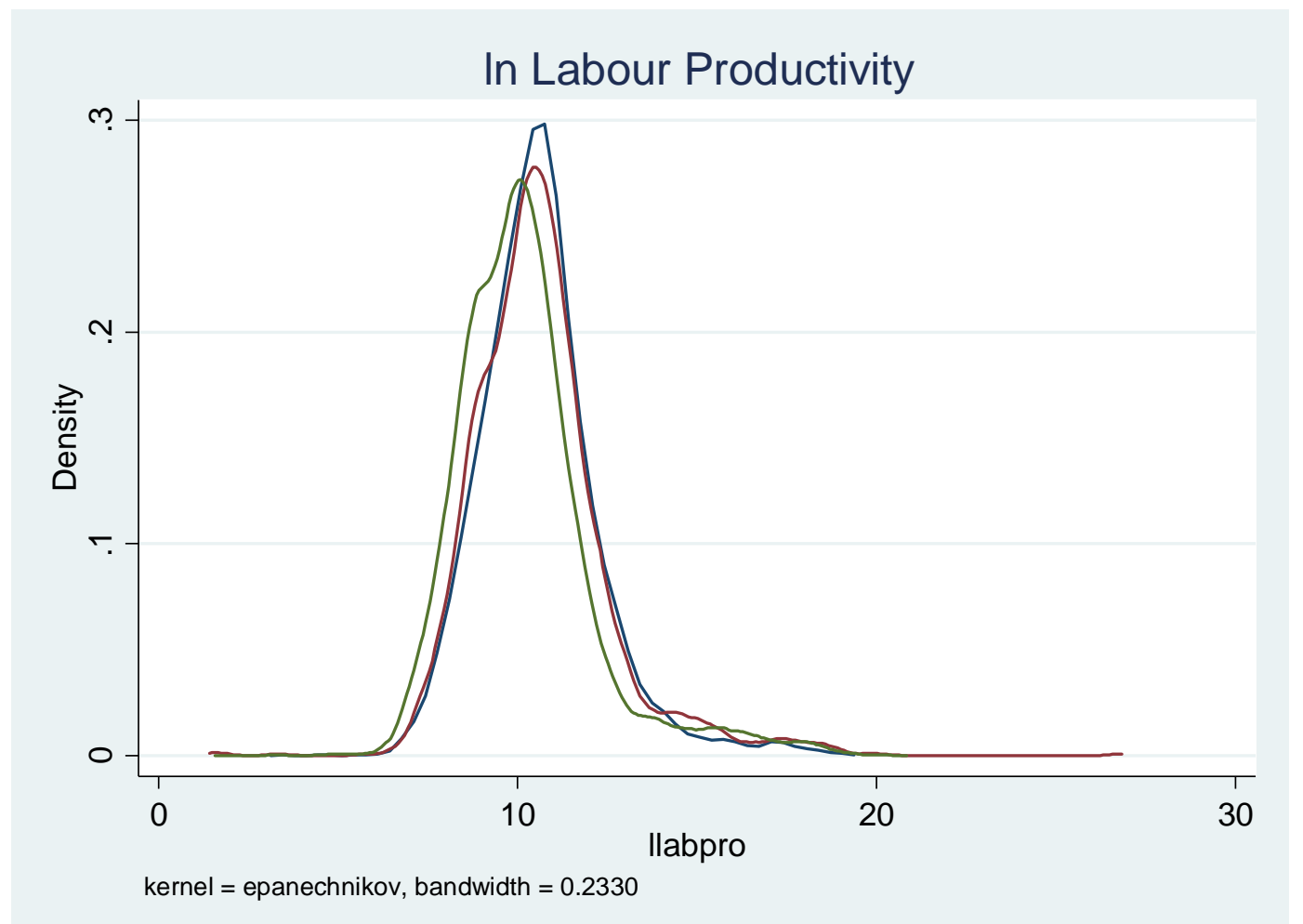

Note: Green colour denotes non-exporters, red denotes indirect exporters and blue direct exporters. Labour productivity is calculated by dividing total annual sales in the last fiscal year by number of permanent, full-time employees of the firm at the end of the last fiscal year. Broad definition of indirect exporters has been used. When using the narrow definition, the overlap between indirect exporters and direct exporters is more notorious. 